\title{
Gordona hirsuta sp. nov.
}

\author{
STEFAN KLATTE, ${ }^{1}$ REINER M. KROPPENSTEDT, ${ }^{2 *}$ PETER SCHUMANN,${ }^{2}$ KARLHEINZ ALTENDORF, ${ }^{3}$ \\ AND FREDERICK A. RAINEY ${ }^{2}$
}

ASTA Medica AG, D-33790 Halle, ${ }^{1}$ DSMZ-Deutsche Sammlung von Mikroorganismen und Zellkulturen GmbH, D-38124 Braunschweig, ${ }^{2}$ and Department of Microbiology, University of Osnabrück, 49082 Osnabrück, ${ }^{3}$ Germany

\begin{abstract}
Bacterial strain $\mathrm{K} 718 \mathrm{a}^{\mathrm{T}}$ ( $\mathrm{T}=$ type strain), which was isolated from the packing material of a biofilter used for deodorization of animal-rendering plant emissions, was subjected to a polyphasic taxonomic study in which physiological, chemotaxonomic, and genomic methods were used. On the basis of the chemotaxonomic and physiological properties found and the results of $16 \mathrm{~S}$ ribosomal DNA sequence comparisons, it was evident that

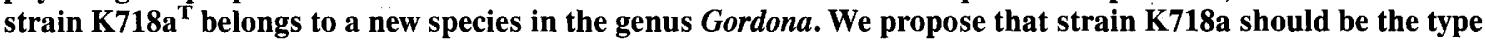
strain of the new species Gordona hirsuta.
\end{abstract}

The genus Gordona is assigned to the suprageneric but phylogenetically coherent group of mycolic acid-containing actinomycetes that also includes the genera Corynebacterium, Mycobacterium, Nocardia, Rhodococcus, Tsukamurella, and Dietzia $(18,20,22)$; these taxa were combined primarily on the basis of similar chemotaxonomic and morphological properties (6). Similar to other taxa of the former rhodochrous complex, the taxonomic status of the genus Gordona was a matter of controversy $(7,25)$ until the distinctness of this taxon from neighboring taxa was confirmed by using phylogenetic and chemotaxonomic results together (23). At present, the genus Gordona comprises seven species, Gordona amarae, Gordona aichiensis, Gordona bronchialis, Gordona hydrophobica, Gordona rubropertincta, Gordona sputi, and Gordona terrae, because of recent reclassifications $(11,21)$ and the inclusion of recently described species (2).

Although a few species (G. aichiensis, G. bronchialis, and $G$. sputi) were originally isolated from clinical specimens $(25,26$, 27 ), it is apparent from the sources of the remaining species and recent studies of the bacterial communities of several aquatic and terrestrial habitats $(1,14)$ that members of the genus Gordona are as widely distributed in the environment as is generally assumed for other mycolic acid-containing actinomycetes (6). Like the recently described organism G. hydrophobica (2), strain $\mathrm{K} 718 \mathrm{a}^{\mathrm{T}}$ ( $\mathrm{T}=$ type strain) was isolated from the packing material (fiber bark compost) of a large-scale biofilter used for biological odor abatement of animal-rendering emissions.

In order to clarify the taxonomic position of strain $\mathrm{K} 718 \mathrm{a}^{\mathrm{T}}$, this organism was subjected to a polyphasic examination of its physiological, chemotaxonomic, and phylogenetic characteristics.

\section{MATERIALS AND METHODS}

Bacterial strains and cultivation. Strain $K 718 \mathrm{a}^{\mathrm{T}}$ and the reference strains used in this study are deposited in the DSMZ-Deutsche Sammlung von Mikroorganismen und Zellkulturen, Braunschweig, Germany. Strain $\mathrm{K} 718 \mathrm{a}^{\mathrm{T}}$ was isolated from wet-ground filter material (fiber bark compost) from a large-scale biofilter on antibiotic sulfonamide sensitivity test agar (Merck, Darmstadt, Germany) by using an agar plate culture technique. For analyses of cellular fatty acids and mycolic acids all strains were grown on TSB agar (3\% [wt/vol] Trypticase soy broth [BBL], $1.5 \%$ [wt/vol] Bacto Agar [Difco]) for 4 days at $28^{\circ} \mathrm{C}$. Physiological properties were determined after growth on GYM agar $(0.4 \%$ [wt/vol] D-glucose, $0.4 \%$ [wt/vol] yeast extract, $1 \%$ [wt/vol] malt extract, $1.2 \%$ [wt/vol] agar no. 1 [Oxoid]) for 3 days at $28^{\circ} \mathrm{C}$. The bacterial biomass used to determine the $\mathrm{G}+\mathrm{C}$

* Corresponding author. Phone: (49-531)-2616 227. Fax: (49-531)2616418 . content of the DNA and for the cell wall analysis was obtained from shake cultures grown in Trypticase soy broth (BBL) for 4 days at $28^{\circ} \mathrm{C}$.

Physiological property tests. Carbon source utilization and qualitative enzyme tests were performed in standard microtitration plates (F-form; Greiner, Nürtingen, Germany) as described previously (10). Briefly, the test panels were inoculated with a standardized bacterial suspension and incubated for $24 \mathrm{~h}$ at $28^{\circ} \mathrm{C}$. After an indicator solution containing the redox dye tetrazolium-[3-(4,5-dimethylthiazol-2-yl)-2,5-diphenyltetrazolium bromide] (MTT) was added to the auxonographic test and control wells (9), the preparations were incubated for an additional $24 \mathrm{~h}$ in the dark. The auxonographic test results were determined photometrically. The results of the enzyme tests were evaluated visually; any visible color indicated that cleavage of the chromogenic substrate had occurred.

Cell wall analysis. Isoprenoid quinones, polar lipids, cell wall diamino acids, and sugars were examined by using previously described methods (12). The acyl type of the peptidoglycan was identified by the method of Uchida and Aida (28), modified by passing the hydrolysate through a cation exchanger (Bond Elut SCX; Varian). Fatty acid methyl esters were prepared from wet cells (40 to $70 \mathrm{mg}$ ) as described previously (17) and were identified by gas chromatography with a model 5898A Microbial Identification System apparatus (Microbial ID, Newark, Del.). Mycolic acids were examined as trimethylsilylated derivatives by hightemperature gas chromatography with a modified model 5898A Microbial Identification System apparatus equipped with a 12-m HT5 column (part 051385; SGE, Victoria, Australia) as described previously (10).

Analysis of DNA base composition. DNA was isolated by using a modification of the Marmur method (15) and was purified by treatment with proteinase $\mathrm{K}$. DNA was degraded to nucleosides by using P1 nuclease and bovine intestinal mucosa alkaline phosphatase as described by Mesbah et al. (16). Nucleosides were separated by reversed-phase high-performance liquid chromatography (HPLC) as described by Tamaoka and Komagata (24). The G+C content was calculated from the ratios of deoxyguanosine and thymidine. The HPLC system used consisted of a model LC-9A solvent delivery module, a model DGU-3a online degasser, a model CTO-10AC column oven, a model SIL-9A automatic sample injector, and a model SPD-6A UV spectrophotometer-detector connected to a model C-R4AX Chromatopac integrator (Shimadzu Corp., Tokyo, Japan).

16S rDNA sequencing. Extraction of genomic DNA and amplification of the 16S ribosomal DNA (rDNA) were carried out as described previously (19). PCR products were sequenced directly by using a Taq DyeDeoxy terminator cycle sequencing kit (Applied Biosystems, Foster City, Calif.) as recommended by the manufacturer. The sequence reaction mixtures were electrophoresed by using an Applied Biosystems model 373A DNA sequencer. The 16S rDNA sequences were aligned manually with the sequences currently available from the public databases. Evolutionary distances were calculated as described by Jukes and Cantor (8). The algorithm of De Soete (3) was used to construct a phylogenetic dendrogram from the distance matrices. The stability of the phylogenetic tree was determined by using the SEQBOOT program (4). A total of 1,000 bootstrapped trees were generated.

Nucleotide sequence accession number. The $16 \mathrm{~S}$ rDNA sequence of strain $\mathrm{K} 718 \mathrm{a}^{\mathrm{T}}$ has been deposited in the EMBL database under accession number X93485.

\section{RESULTS}

Cell wall analysis. The cell wall analysis of strain $\mathrm{K} 718 \mathrm{a}^{\mathrm{T}}$ revealed that the wall chemotype was chemotype IV sensu Lechevalier and Lechevalier (13) on the basis of the following combination of diagnostic cell wall properties: arabinose and galactose were major cell wall sugars, meso-diaminopimelic 
TABLE 1. Cellular fatty acids of $G$. hirsuta and the type strains of species of the genus Gordona

\begin{tabular}{|c|c|c|c|c|c|c|c|c|c|c|}
\hline \multirow[b]{2}{*}{ Strain } & \multicolumn{10}{|c|}{ Cellular fatty acid composition $(\%)^{a}$} \\
\hline & $14: 0$ & $15: 0$ & $\begin{array}{l}16: 1 \\
\text { cis } 9\end{array}$ & $\begin{array}{c}16: 1 \\
\text { cis } 10\end{array}$ & $16: 0$ & $\begin{array}{l}17: 1 \\
\text { cis } 9\end{array}$ & $17: 0$ & $\begin{array}{l}18: 1 \\
\text { cis } 9\end{array}$ & $18: 0$ & TBSA $^{b}$ \\
\hline G. aichiensis DSM $43978^{\mathrm{T}}$ & 2 & 1 & & 13 & 34 & 1 & 1 & 17 & 2 & 25 \\
\hline G. amarae DSM $43392^{\mathrm{T}}$ & 1 & 1 & 3 & 15 & 29 & 2 & 1 & 24 & 1 & 21 \\
\hline G. bronchialis DSM $43247^{\mathrm{T}}$ & 1 & 1 & 11 & 16 & 23 & 2 & 1 & 10 & 1 & 20 \\
\hline G. hirsuta DSM $44140^{\mathrm{T}}$ & 2 & & 1 & 16 & 30 & 1 & 1 & 30 & 3 & 17 \\
\hline G. hydrophobica DSM $44015^{\mathrm{T}}$ & 1 & 4 & & 13 & 27 & 4 & 4 & 14 & 1 & 26 \\
\hline G. rubropertincta DSM $43197^{\mathrm{T}}$ & 2 & 2 & & 15 & 25 & 5 & 3 & 24 & & 17 \\
\hline G. sputi DSM $43896^{\mathrm{T}}$ & 2 & 2 & & & 44 & 2 & 2 & 29 & & 15 \\
\hline G. terrae DSM $43249^{\mathrm{T}}$ & 2 & 1 & & 16 & 32 & 1 & 1 & 26 & 2 & 19 \\
\hline
\end{tabular}

${ }^{a}$ Main components. In addition, G. hydrophobica contains $2 \% 15: 1$ cis 10 and 10-Met-17:0.

${ }^{b}$ TBSA, tuberculostearic acid (10-Met-18:0).

acid was the only diamino acid, and $N$-glycolated muramic acid moieties of peptidoglycan were present. The polar lipids were composed of diphosphatidylglycerol, phosphatidylinositol,phosphatidylinositol mannosides, and phosphatidylethanolamine. Menaquinone MK-9 $\left(\mathrm{H}_{2}\right)$ was the predominant isoprenolog, and minor amounts of menaquinone $\mathrm{MK}-8\left(\mathrm{H}_{2}\right)$ were also present.

Cellular fatty and mycolic acids. An analysis of the simple fatty acids obtained from whole cells of strain $K 718 \mathrm{a}^{\mathrm{T}}$ revealed that the cells contained straight-chain, saturated and unsaturated fatty acids and significant amounts of tuberculostearic acid (10-methyl octadecanoic acid) (Table 1). The chain lengths of the mycolic acids, as determined from trimethylsilylated derivatives by high-temperature gas chromatography, ranged from 60 to 64 carbon atoms (Table 2), and the mean chain length was 62 carbon atoms.

Physiological tests. The physiological properties of strain $\mathrm{K} 718 \mathrm{a}^{\mathrm{T}}$ are shown in Table 3 . As determined by MTT reduction, strain $\mathrm{K} 718 \mathrm{a}^{\mathrm{T}}$ utilized only D-galactose, meso-inositol, and 2-oxoglutarate of the 31 carbon sources tested and also enzymatically hydrolyzed the chromogenic substrate $p$-nitrophenyl (pNP)-phosphorylcholine.

$\mathrm{G}+\mathbf{C}$ content of the DNA. The $\mathrm{G}+\mathrm{C}$ content of the DNA of strain $\mathrm{K} 718 \mathrm{a}^{\mathrm{T}}$, as determined by HPLC, was $69 \mathrm{~mol} \%$.

Analysis of 16S rDNA. An almost complete $16 \mathrm{~S}$ rDNA sequence of strain $\mathrm{K} 718 \mathrm{a}^{\mathrm{T}}$ was determined and compared with the sequences of all previously validly described Gordona species and additional reference strains of related, mycolic acidcontaining actinomycetes. As shown in the phylogenetic tree in Fig. 1, strain $\mathrm{K} 718 \mathrm{a}^{\mathrm{T}}$ and all of the representatives of the genus Gordona clearly grouped in a single cluster that could be recovered in $100 \%$ of the samples as determined by bootstrap analysis (data not shown). However, the branching order in the Gordona group (except for $G$. aichiensis and $G$. sputi) is not stable because of the short distances between branches. In addition, the highest levels of sequence similarity were the levels of similarity between strain $\mathrm{K} 718 \mathrm{a}^{\mathrm{T}}$ and previously described Gordona species (96.7 to $95.8 \%$ ), while the levels of similarity to members of other genera were distinctly lower $(<93.9 \%)$ (Table 4).

\section{DISCUSSION}

On the basis of the results of this work, it is evident that strain $\mathrm{K} 718 \mathrm{a}^{\mathrm{T}}$ represents a new Gordona species that has all of the characteristic chemotaxonomic markers of the genus Gordona (6), including an MK-9 $\left(\mathrm{H}_{2}\right)$ type of menaquinone, simple mycolic acids ranging in size form ca. 60 to 64 carbons, and straight-chain saturated and unsaturated fatty acids along with significant amounts of tuberculostearic acid. It is also clear that strain $\mathrm{K} 718 \mathrm{a}^{\mathrm{T}}$ can be differentiated from all previously described Gordona species on the basis of physiological reactions and fatty acid profiles. Furthermore, the polyphasic assignment of this strain to the genus Gordona was confirmed by the results of $16 \mathrm{~S}$ rDNA sequence comparisons and phylogenetic analyses which included all previously validly described Gordona species and additional reference strains of other mycolic acid-containing actinomycetes. We propose that strain $\mathrm{K} 718 \mathrm{a}$ should be the type strain of a new Gordona species, Gordona hirsuta.

So far, little is known about the participation or possible role in environmental remediation processes of the Gordona species that have been isolated from scumming activated sludge in aeration tanks of biological sewage treatment plants (14) or

TABLE 2. Mycolic acids of G. hirsuta and the type strains of species of the genus Gordona

\begin{tabular}{|c|c|c|c|c|c|c|c|c|c|c|c|c|c|c|c|c|}
\hline \multirow{2}{*}{ Strain } & \multicolumn{16}{|c|}{ Mycolic acid composition (\%) } \\
\hline & $\mathrm{C}_{48}{ }^{b}$ & $\mathrm{C}_{50}$ & $\mathrm{C}_{51}$ & $\mathrm{C}_{52}$ & $\mathrm{C}_{53}$ & $\mathrm{C}_{54}$ & $\mathrm{C}_{55}$ & $\mathrm{C}_{56}$ & $\mathrm{C}_{57}$ & $\mathrm{C}_{58}$ & $\mathrm{C}_{59}$ & $\mathrm{C}_{60}$ & $\mathrm{C}_{61}$ & $\mathrm{C}_{62}$ & $\mathrm{C}_{63}$ & $\mathrm{C}_{64}$ \\
\hline G. aichiensis DSM $43978^{\mathrm{T}}$ & & & & & & & & & & & & 14 & 11 & 47 & 11 & 17 \\
\hline G. amarae DSM $43392^{\mathrm{T}}$ & 5 & 30 & 3 & 40 & 4 & 18 & & & & & & & & & & \\
\hline G. bronchialis DSM $43247^{\mathrm{T}}$ & & & & & & & & & & & & 8 & 21 & 25 & 25 & 13 \\
\hline G. hirsuta DSM $44140^{\mathrm{T}}$ & & & & & & & & & & & & 19 & 10 & 31 & 9 & 31 \\
\hline G. hydrophobica DSM $44015^{\mathrm{T}}$ & & & & & & & & 12 & 11 & 30 & 16 & 26 & 5 & & & \\
\hline G. rubropertincta DSM $43197^{\mathrm{T}}$ & & & & & & 4 & 3 & 14 & 11 & 23 & 17 & 18 & 5 & 6 & & \\
\hline G. sputi DSM $43896^{\mathrm{T}}$ & & & & & & & & & & & & 8 & 12 & 48 & 14 & 8 \\
\hline G. terrae DSM $43249^{\mathrm{T}}$ & & & & & & 5 & 1 & 27 & 4 & 36 & 3 & 19 & 1 & 4 & & \\
\hline
\end{tabular}

\footnotetext{
${ }^{a}$ Main components.

${ }^{b}$ The designations indicate the chain lengths of the mycolic acids (numbers of carbon atoms).
} 
TABLE 3. Physiological properties of $G$. hirsuta and the type strains of species of the genus Gordona

\begin{tabular}{|c|c|c|c|c|c|c|c|c|}
\hline $\begin{array}{c}\text { Compound assimilated } \\
\text { or cleaved }\end{array}$ & $\begin{array}{l}\text { G. aichiensis } \\
\text { DSM } 43978^{\mathrm{T}}\end{array}$ & $\begin{array}{l}\text { G. amarae } \\
\text { DSM } 43392^{\mathrm{T}}\end{array}$ & $\begin{array}{l}\text { G. bronchialis } \\
\text { DSM } 43247^{\mathrm{T}}\end{array}$ & $\begin{array}{l}\text { G. hirsuta } \\
\text { DSM } 44140^{T}\end{array}$ & $\begin{array}{l}\text { G. hydrophobica } \\
\text { DSM } 44015^{\mathrm{T}}\end{array}$ & $\begin{array}{l}\text { G. rubropertincta } \\
\text { DSM } 43197^{\mathrm{T}}\end{array}$ & $\begin{array}{c}\text { G. sputi } \\
\text { DSM } 43896^{\mathrm{T}}\end{array}$ & $\begin{array}{c}\text { G. terrae } \\
\text { DSM } 43249^{\mathrm{T}}\end{array}$ \\
\hline$N$-Acetyl-D-glucosamine & $-{ }^{a}$ & - & + & - & - & - & - & - \\
\hline Glucarate & - & - & - & - & + & + & - & + \\
\hline Gluconate & - & - & + & - & - & + & - & - \\
\hline D-Glucosaminic acid & - & - & - & - & - & + & - & - \\
\hline L-Rhamnose & - & - & + & - & - & + & - & + \\
\hline D-Ribose & - & + & - & - & - & + & - & - \\
\hline D-Sucrose & - & + & + & - & + & + & - & + \\
\hline D-Turanose & - & + & + & - & + & - & - & - \\
\hline D-Arabitol & - & + & - & - & - & + & + & + \\
\hline$I$-Inositol & - & - & + & + & - & - & - & - \\
\hline Citrate & + & + & - & - & + & - & + & + \\
\hline 2-Hydroxyvalerate & - & - & - & + & - & - & - & - \\
\hline 2-Oxoglutarate & + & + & - & + & - & - & + & + \\
\hline Succinate & - & - & + & - & + & - & + & - \\
\hline L-Alanine & + & - & + & - & - & + & - & - \\
\hline 4-Aminobenzoate & + & - & - & - & - & - & - & - \\
\hline L-Aspartate & + & - & - & - & - & - & - & - \\
\hline L-Leucine & - & - & + & - & + & - & - & - \\
\hline L-Proline & - & + & - & - & + & - & - & - \\
\hline L-Valine & - & + & + & - & + & - & - & - \\
\hline Putrescine & - & + & - & - & - & - & + & - \\
\hline Acetamide & - & - & + & - & + & - & - & - \\
\hline Benzoate & - & - & - & - & - & + & - & + \\
\hline 4-Hydroxybenzoate & - & + & + & - & - & - & - & - \\
\hline Phenylactic acid & - & - & + & - & - & + & - & - \\
\hline Quinate & + & + & - & - & - & - & - & - \\
\hline pNP- $\beta$-D-xyloside & - & - & - & - & - & - & - & + \\
\hline pNP-phosphorylcholine & - & - & - & + & + & - & - & - \\
\hline $\begin{array}{l}\text { 2-Deoxythymidine-5' - } \\
\text { pNP-phosphate }\end{array}$ & - & - & - & - & + & - & - & - \\
\hline
\end{tabular}

${ }^{a}$ Assimilation of auxonographic substrates was detected photometrically by means of reduction of the redox dye MTT.,$+ E_{540}($ test $)-E_{540}($ control) $>0.129 ;-$ $E_{540}$ (test) $-E_{540}($ control $) \leq 0.129$. All strains tested were positive for D-galactose and negative for pimelic acid, L-serine, tyramine, and 3-hydroxybenzoate.

TABLE 4. Levels of 16S rDNA sequence similarity between $G$. hirsuta and related taxa

\begin{tabular}{|c|c|c|c|c|c|c|c|c|c|c|c|c|c|c|c|c|c|c|c|}
\hline \multirow[b]{2}{*}{ Species } & \multicolumn{19}{|c|}{$\% 16 \mathrm{~S}$ rDNA sequence similarity } \\
\hline & 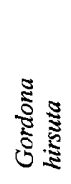 & 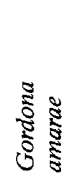 & 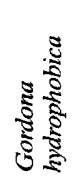 & : & 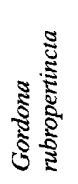 & 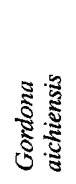 & 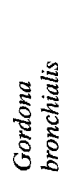 & 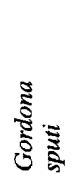 & 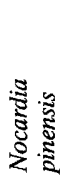 & 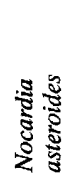 & 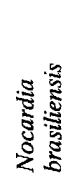 & 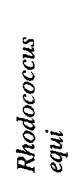 & 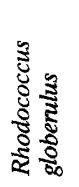 & 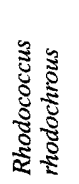 & 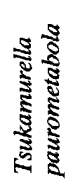 & 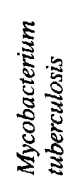 & 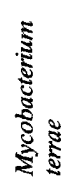 & ปั้ & 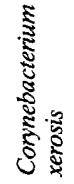 \\
\hline Gordona amarae & 96.7 & & & & & & & & & & & & & & & & & & \\
\hline Gordona hydrophobica & 96.4 & 97.6 & & & & & & & & & & & & & & & & & \\
\hline Gordona terrae & 96.2 & 97.4 & 97.5 & & & & & & & & & & & & & & & & \\
\hline Gordona rubropertincta & 96.1 & 97.2 & 98.0 & 98.3 & & & & & & & & & & & & & & & \\
\hline Gordona aichiensis & 96.0 & 96.6 & 96.5 & 96.9 & 97.2 & & & & & & & & & & & & & & \\
\hline Gordona bronchialis & 95.8 & 97.2 & 97.2 & 98.3 & 98.5 & 97.6 & & & & & & & & & & & & & \\
\hline Gordona sputi & 95.7 & 96.5 & 96.4 & 96.8 & 96.8 & 99.7 & 97.4 & & & & & & & & & & & & \\
\hline Nocardia pinensis & 93.2 & 94.7 & 94.0 & 94.8 & 94.6 & 94.2 & 95.0 & 93.9 & & & & & & & & & & & \\
\hline Nocardia asteroides & 93.1 & 93.9 & 93.3 & 93.4 & 93.4 & 92.8 & 93.5 & 92.8 & 93.5 & & & & & & & & & & \\
\hline Nocardia brasiliensis & 93.6 & 94.8 & 94.2 & 94.4 & 94.6 & 93.9 & 94.8 & 93.9 & 93.9 & 97.7 & & & & & & & & & \\
\hline Rhodococcus equi & 93.4 & 94.2 & 93.9 & 94.6 & 94.3 & 93.4 & 94.4 & 93.2 & 94.9 & 96.3 & 96.3 & & & & & & & & \\
\hline Rhodococcus globerulus & 93.0 & 93.3 & 93.1 & 93.5 & 93.5 & 92.8 & 93.9 & 92.7 & 94.0 & 95.1 & 95.0 & 96.5 & & & & & & & \\
\hline Rhodococcus rhodochrous & 93.9 & 94.1 & 93.7 & 94.5 & 94.3 & 94.0 & 94.4 & 93.9 & 94.3 & 94.0 & 94.4 & 96.2 & 95.1 & & & & & & \\
\hline Tsukamurella paurometabola & 93.6 & 94.6 & 93.5 & 93.4 & 93.3 & 93.4 & 93.5 & 93.4 & 93.1 & 94.6 & 93.8 & 94.9 & 94.7 & 94.6 & & & & & \\
\hline Mycobacterium tuberculosis & 90.9 & 92.0 & 91.9 & 92.5 & 91.9 & 91.5 & 92.8 & 91.3 & 92.5 & 92.8 & 91.9 & 92.4 & 92.1 & 92.0 & 92.3 & & & & \\
\hline Mycobacterium terrae & 92.4 & 93.2 & 92.8 & 93.1 & 92.8 & 93.0 & 93.2 & 92.7 & 94.6 & 93.5 & 92.8 & 93.1 & 93.1 & 93.5 & 94.1 & 96.8 & & & \\
\hline Dietzia maris & 93.5 & 93.8 & 93.0 & 93.1 & 92.8 & 92.9 & 93.1 & 92.8 & 92.6 & 93.2 & 92.8 & 94.2 & 94.9 & 94.6 & 95.3 & 91.9 & 93.1 & & \\
\hline Corynebacterium xerosis & 90.7 & 91.3 & 91.5 & 91.7 & 91.5 & 91.2 & 92.3 & 91.2 & 91.5 & 90.8 & 90.5 & 92.0 & 92.0 & 92.5 & 92.4 & 92.3 & 92.3 & 93.5 & \\
\hline Corynebacterium glutamicum & 89.6 & 89.4 & 89.5 & 89.8 & 90.0 & 89.2 & 90.1 & 89.5 & 90.1 & 89.2 & 89.3 & 90.8 & 90.8 & 91.5 & 90.5 & 89.2 & 89.6 & 91.3 & 93.5 \\
\hline
\end{tabular}




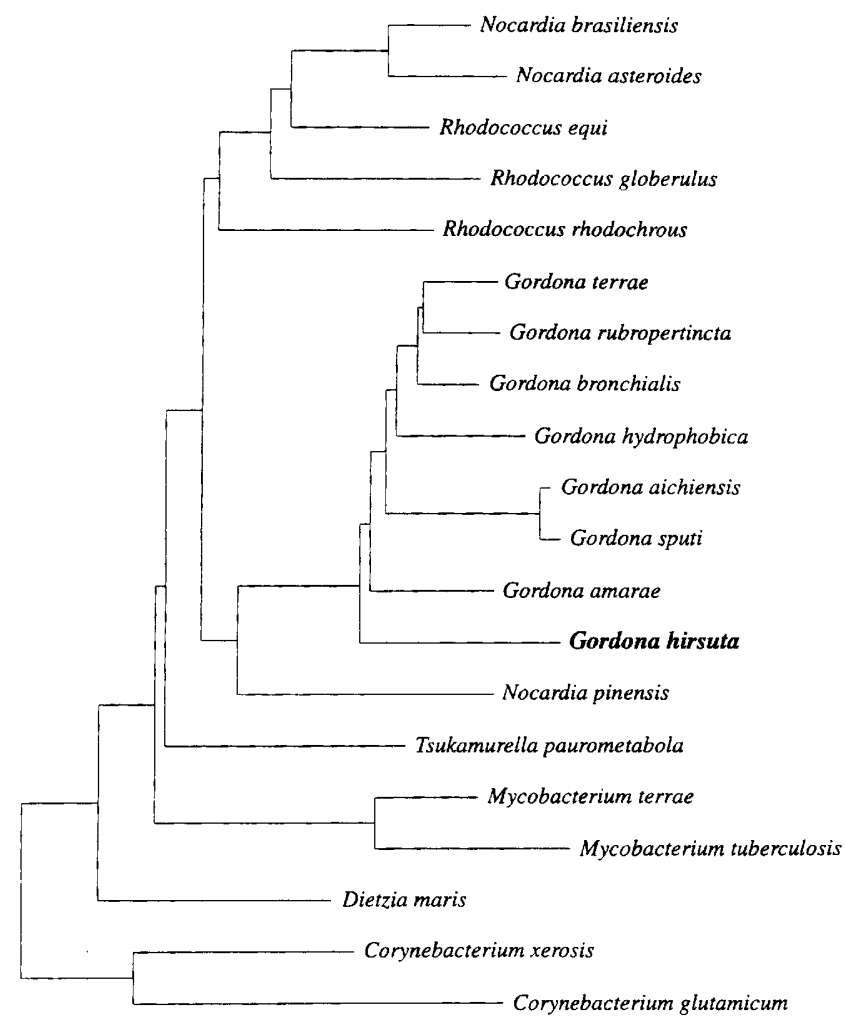

$5 \%$

FIG. 1. Phylogenetic dendrogram based on 16S rDNA sequence comparisons showing the position of Gordona hirsuta within the Gordona cluster of the mycolic acid-containing actinomycetes. The scale bar represents 5 nucleotide substitutions per 100 nucleotides. All reference sequences included are those of type strains.

biofilters used for the treatment of malodorous animal-rendering emissions (2), although the extraordinary degradative and enzymatic capabilities found in members of the closely related actinomycete genus Rhodococcus (5) suggest that extended investigations of the physiological properties of members of the genus Gordona should be performed. Nevertheless, the first step necessary for determining the possible roles of microorganisms in their environments is still a reliable classification, and several polyphasic approaches, in which chemotaxonomic and phylogenetic procedures have been combined, have been used successfully to discover novel Gordona species recently $(2,11)$.

Description of Gordona hirsuta sp. nov. Gordona hirsuta (hir. su'ta. L. adj. hirsuta, shaggy, rough, referring to the rough surface of the colonies). Gram-positive, non-acid-fast, nonmotile, strictly aerobic rods that grow amycelially. White to light yellow colonies with irregular margins and flat, rough surfaces are formed on various media. Catalase positive and oxidase negative. Hydrolyzes pNP-phosphorylcholine, but not 2-deoxythymidine- 5 ' - pNP-phosphate and $\mathrm{pNP}-\beta-\mathrm{D}-\mathrm{xyloside}$. As determined by MTT reduction, D-galactose, meso-inositol, and 2-oxoglutarate are metabolized, but $N$-acetyl-D-glucosamine, gluconate, D-glucosaminic acid, citrate, benzoate, 3-hydroxybenzoate, 4-hydroxybenzoate, 4-aminobenzoate, 2-hydroxyvalerate, phenylacetic acid, pimelate, succinate, quinate, L-alanine, L-aspartate, L-leucine, L-serine, L-proline, L-valine, putrescine, tyramine, D-ribose, D-sucrose, D-turanose, D-arabitol, L-rhamnose, glucarate, and acetamide are not utilized.

The cell wall type is of wall chemotype IV sensu Lechevalier and Lechevalier; meso-diaminopimelic acid is the only diamino acid, arabinose and galactose are major cell wall sugars, and $N$-glycolated muramic acid moieties of peptidoglycan are present. The predominant menaquinone is menaquinone MK$9\left(\mathrm{H}_{2}\right)$. The polar lipids are composed of diphosphatidylglycerol, phosphatidylethanolamine, phosphatidylinositol, and phosphatidylinositol mannosides. Contains major amounts of straight-chain, saturated and unsaturated fatty acids and tuberculostearic acid. Mycolic acids with 60 to 64 carbon atoms are present.

The $\mathrm{G}+\mathrm{C}$ content of the DNA of the type strain is $69 \mathrm{~mol} \%$ (as determined by the HPLC method).

The type strain was isolated from the packing material (tree bark compost) of a large-scale biofilter used for deodorization of animal-rendering emissions.

The type strain is strain K718a (= DSMZ $44140^{\mathrm{T}}$ ).

\section{REFERENCES}

1. Bendinger, B., R. M. Kroppenstedt, S. Klatte, and K. Altendorf. 1992. Chemotaxonomic differentiation of coryneform bacteria isolated from biofilters. Int. J. Syst. Bacteriol. 42:474 486.

2. Bendinger, B., F. A. Rainey, M. Moormann, R. M. Kroppenstedt, and S. Klatte. 1995. Gordona hydrophobica sp. nov., isolated from biofilters for waste gas treatment. Int. J. Syst. Bacteriol. 45:544-548.

3. De Soete, G. 1983. A least squares algorithm for fitting additive trees to proximity data. Psychometrika 48:621-626.

4. Felsenstein, J. 1993. PHYLIP (phylogeny inference package), version 3.5c Department of Genetics, University of Washington, Seattle.

5. Finnerty, W. R. 1992. The biology and genetics of the genus Rhodococcus. Annu. Rev. Microbiol. 46:193-218.

6. Goodfellow, M. 1992. The family Nocardiaceae, p. 1188-1213. In A. Balows, H. G. Trüper, M. Dworkin, W. Harder, and K. H. Schleifer (ed.), The prokaryotes, 2nd ed. Springer-Verlag, New York.

7. Goodfellow, M., and G. Alderson. 1977. The actinomycete genus Rhodococcus: a home for the 'rhodochrous' complex. J. Gen. Microbiol. 100:99-122.

8. Jukes, T. H., and C. R. Cantor. 1969. Evolution of protein molecules, p. 21-132. In H. N. Munro (ed.), Mammalian protein metabolism. Academic Press, New York.

9. Kirchhof, H., C. Maas, M. Runge, B. Franz, R. Schmidt, H. Quentmeier, and P. F. Mühlhardt. 1992. Tetrazolium-[3-(4,5-dimethylthiazol-2-yl)-2,5-diphenyltetrazolium bromide] reduction by mycoplasmas. Int. J. Syst. Bacteriol. 42:506-508

10. Klatte, S., R. M. Kroppenstedt, and F. A. Rainey. 1994. Rhodococcus opacus sp. nov., an unusual nutritionally versatile Rhodococcus species. Syst. Appl. Microbiol. 17:355-360.

11. Klatte, S., F. A. Rainey, and R. M. Kroppenstedt. 1994. Transfer of Rhodococcus aichiensis Tsukamura 1982 and Nocardia amarae Lechevalier and Lechevalier 1974 to the genus Gordona as Gordona aichiensis comb. nov. and Gordona amarae comb. nov. Int. J. Syst. Bacteriol. 44:769-773.

12. Kothe, H. W., G. Vobis, R. M. Kroppenstedt, and A. Henssen. 1989. A taxonomic study of mycolateless, wall chemotype IV actinomycetes. Syst. Appl. Microbiol. 12:61-69.

13. Lechevalier, H. A., and M. P. Lechevalier. 1970. Chemical composition as a criterion in the classification of aerobic actinomycetes. Int. J. Syst. Bacteriol. 20:435-444.

14. Lemmer, H., and R. M. Kroppenstedt. 1984. Chemotaxonomy and physiology of some actinomycetes isolated from scumming activated sludge. Syst. Appl. Microbiol. 5:124-135.

15. Marmur, J. 1961. A procedure for the isolation of deoxyribonucleic acid from microorganisms. J. Mol. Biol. 3:208-218.

16. Mesbah, M., U. Premachandran, and W. B. Whitman. 1989. Precise measurement of the $\mathrm{G}+\mathrm{C}$ content of deoxyribonucleic acid by high-performance liquid chromatography. Int. J. Syst. Bacteriol. 39:159-167.

17. Miller, $L$., and T. Berger. 1985 . Bacterial identification by gas chromatography of whole cell fatty acids. Gas chromatography applications note 228 41. Hewlett-Packard Co., Palo Alto, Calif.

18. Rainey, F. A., J. Burghardt, R. M. Kroppenstedt, S. Klatte, and E. Stackebrandt. 1995. Phylogenetic analysis of the genera Rhodococcus and Nocardia and evidence for the evolutionary origin of the genus Nocardia from within the radiation of Rhodococcus species. Microbiology 141:523-528.

19. Rainey, F. A., M. Dorsch, H. W. Morgan, and E. Stackebrandt. 1992. 16S rDNA analysis of Spirochaeta thermophila: its phylogenetic position and implications for the systematics of the order Spirochaetales. Syst. Appl. Microbiol. 16:224-226. 
20. Rainey, F. A., S. Klatte, R. M. Kroppenstedt, and E. Stackebrandt. 1995 Dietzia, a new genus including Dietzia maris comb. nov., formerly Rhodococcus maris. Int. J. Syst Bacteriol. 45:32-36.

21. Riegel, P., M. V. Kame-Fotso, D. De Briel, G. Prévost, F. Jehl, Y. Piémont, and H. Monteil. 1994. Rhodococcus chubuensis Tsukamura 1982 is a later subjective synonym of Gordona sputi (Tsukamura 1978) Stackebrandt 1989 comb. nov. Int. J. Syst. Bacteriol. 44:764-768.

22. Ruimy, R., P. Boiron, V. Boivin, and R. Christen. 1994. A phylogeny of the genus Nocardia deduced from the analysis of small-subunit ribosomal DNA sequences, including transfer of Nocardia amarae to the genus Gordona as Gordona amarae comb. nov. FEMS Microbiol. Lett. 123:261-268.

23. Stackebrandt, E., J. Smida, and M. D. Collins. 1988. Evidence of phylogenetic heterogeneity within the genus Rhodococcus: revival of the genus Gordona (Tsukamura). J. Gen. Appl. Microbiol. 34:341-348.

24. Tamaoka, J., and K. Komagata. 1984. Determination of DNA base composition by reversed-phase high-performance liquid chromatography. FEMS
Microbiol. Lett. 25:125-128.

25. Tsukamura, M. 1971. Proposal of a new genus, Gordona, for slightly acidfast organisms occuring in sputa of patients with pulmonary disease and in soil. J. Gen. Microbiol. 68:15-26.

26. Tsukamura, M. 1978. Numerical classification of Rhodococcus (formerly Gordona) organisms recently isolated from sputa of patients: description of Rhodococcus sputi Tsukamura sp. nov. Int. J. Syst. Bacteriol. 28:169-181.

27. Tsukamura, M. 1982 . Numerical analysis of the taxonomy of nocardiae and rhodococci. Division of Nocardia asteroides sensu stricto into two species and description of Nocardia paratuberculosis sp. nov. Tsukamura (formerly the Kyoto-I group of Tsukamura), Nocardia nova sp. nov. Tsukamura, Rhodococcus aichiensis sp. nov. Tsukamura, Rhodococcus chubunensis sp. nov. Tsukamura, and Rhodococcus obuensis sp. nov. Tsukamura. Microbiol. Immunol. 26:1101-1119.

28. Uchida, K., and K. Aida. 1977. Acyl type of bacterial cell wall: its simple identification by a colorimetric method. J. Gen. Microbiol. 23:249-260. 